\title{
Article \\ Effect of Lintel Beam on Seismic Response of Reinforced Concrete Buildings with Semi-Interlocked and Unreinforced Brick Masonry Infills
}

\author{
Mangeshkumar R. Shendkar ${ }^{1}$ D , Denise-Penelope N. Kontoni ${ }^{2, *(D)}$, Sasankasekhar Mandal ${ }^{1}$, \\ Pabitra Ranjan Maiti ${ }^{1}$ and Dipendra Gautam ${ }^{3}$ \\ 1 Department of Civil Engineering, Indian Institute of Technology (IIT-BHU), Varanasi 221 005, India; \\ mrajkumar.shendkar.rs.civ18@iitbhu.ac.in (M.R.S.); smandal.civ@itbhu.ac.in (S.M.); \\ prmaiti.civ@itbhu.ac.in (P.R.M.) \\ 2 Department of Civil Engineering, University of the Peloponnese, GR-26334 Patras, Greece \\ 3 Department of Architecture and Civil Engineering, City University of Hong Kong, Kowloon, Hong Kong; \\ dip.gautam@my.cityu.edu.hk \\ * Correspondence: kontoni@uop.gr; Tel.: +30-2610-369031
}

\section{check for} updates

Citation: Shendkar, M.R.; Kontoni, D.-P.N.; Mandal, S.;

Maiti, P.R.; Gautam, D. Effect of Lintel Beam on Seismic Response of

Reinforced Concrete Buildings with Semi-Interlocked and Unreinforced Brick Masonry Infills. Infrastructures 2021, 6, 6. https://doi.org/10.3390/ infrastructures 6010006

Received: 22 November 2020 Accepted: 29 December 2020 Published: 1 January 2021

Publisher's Note: MDPI stays neutral with regard to jurisdictional clai$\mathrm{ms}$ in published maps and institutional affiliations.

Copyright: (C) 2021 by the authors. Licensee MDPI, Basel, Switzerland. This article is an open access article distributed under the terms and conditions of the Creative Commons Attribution (CC BY) license (https:// creativecommons.org/licenses/by/ $4.0 /)$.
Abstract: The primary focus of this study is to evaluate the nonlinear response of reinforced concrete (RC) frames with two types of brick infills viz., unreinforced brick masonry infill (URM) and semiinterlocked brick masonry infill (SIM) together with lintel beams, subjected to seismic loads. The seismic response is quantified in terms of response reduction factor and base shear. Infill walls are modeled using double strut nonlinear cyclic element. Nonlinear static adaptive pushover analysis is performed in the finite element program SeismoStruct. The response reduction factor $(\mathrm{R})$ is computed from adaptive pushover analysis and performance for all models is obtained. The results showed that the average $\mathrm{R}$ factor of the RC framed structure with semi-interlocked masonry (SIM) is 1.31 times higher than the RC frame with unreinforced masonry (URM) infill. The R value of the bare frame with the lintel beam is found to be less than the corresponding value recommended in the Indian Standard Code. The results obtained in this study highlight that if the impacts of lintel beams and various brick infill scenarios are considered in the $\mathrm{RC}$ frames then the $\mathrm{R}$ values used for the design of RC frame buildings with infills would be underestimated (i.e., the evaluated $\mathrm{R}$ values are greater than the $\mathrm{R}$ values used for the design purpose).

Keywords: brick masonry infill; semi-interlocked brick masonry infill; response reduction factor; base shear; lintel beam; RC frame

\section{Introduction}

Currently, reinforced concrete (RC) with masonry infill walls is the most dominant construction system worldwide. Masonry infill walls are one of the most affected components during earthquakes as observed during recent earthquakes [1,2]. As masonry infills are one of the most vulnerable nonstructural components, quantification of seismic performance of masonry infills is currently gaining momentum. Although masonry panels are nonstructural components, their presence in the frames has a huge impact on the seismic response of structures as they increase structural strength as well as stiffness. Many seismic design codes provide guidelines to incorporate structural nonlinearity by using the response reduction factor (response modification factor or behavior factor). Seismic codes across the globe have different provisions for the response reduction factor for various types of buildings forms. However, in most countries, seismic codes do not address the effect of the lintel beam on the response reduction factor. Furthermore, construction of soft story as the ground floor is common, especially in developing countries. Thus, the seismic response of such open ground story buildings will be different than the RC buildings with all walls provided with infill walls. However, studies comprising the combined scenario of 
lintel beam, soft story, and other scenarios are limited. Semi-interlocked masonry (SIM) is a new type of masonry that comprises dry stack semi-interlocking brick units as shown in Figure 1 [3]. Semi-interlocked masonry is mortarless, so it is a fast and affordable construction system. Such SIM panels depict relative shear sliding mechanism in in-plane and interlocking mechanism in out-of-plane direction $[3,4]$.

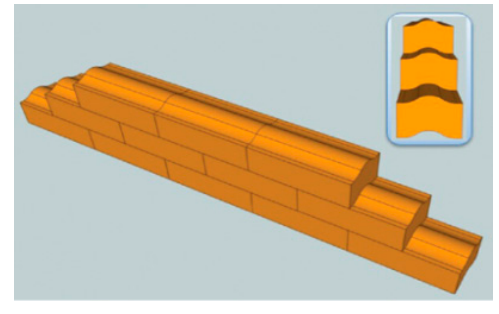

(a)

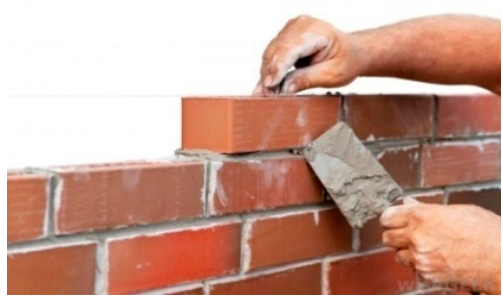

(b)

Figure 1. Infill materials: (a) semi-interlocked masonry (SIM); (b) unreinforced masonry (URM) [3].

Wang et al. [3] developed an innovative masonry system as-interlocking masonry (SIM) unit, which is capable of assuring relative sliding in in-plane direction and interlocking in out-of-plane direction. The main objective of the system was to enhance the seismic performance of framed structures with masonry panels acting as energy dissipation devices. The authors showed the results of numerical simulation of SIM units in steel frame, which confirmed appreciable seismic behavior of the panels [3]. Wang et al. [4] studied the effect of SIM infill panels on structural parameters such as yield displacement, ductility, and damage mechanisms of a multi-story steel frame structures by using the finite element program SeismoStruct, considering static pushover analysis scheme. They concluded that SIM infill may have the potential to reduce damage in a building during an earthquake [4]. Alguhane et al. [5] presented a study on the seismic evaluation of an existing 5-storied RC building with different infill configurations in Madinah city. They presented four model systems as bare frame, frame with infill from field test, frame infilled as per ASCE 41, and frame infilled together with open ground story according to ASCE 41. The response modification factor (R) for the 5-story RC building was evaluated from capacity and demand spectra (ATC-40) for all models. The authors concluded that the R factor increases due to the presence of infill and it satisfies the requirement of the code (Saudi Building Code (SBC) 301) but the bare frame does not satisfy the requirement of the response modification factor [5]. Shendkar and Pradeep Kumar [6] presented a numerical simulation of RC semi-interlocked masonry (SIM) and unreinforced masonry (URM) frame. The response reduction factor was evaluated using pushover analysis and the R-value was found to be higher in the RC SIM panel frame when compared to the RC URM panel frame. This is because the SIM panel acts as an energy dissipating device due to its geometrical shape. Moreover, the authors concluded that $\mathrm{R}$ factor is sensitive to material and geometrical configuration [6]. Chaulagain et al. [7] evaluated the response reduction factor of 12 existing irregular reinforced concrete buildings in Kathmandu Valley using pushover analysis. They concluded that the computed average value of $\mathrm{R}(=3.40)$ obtained for different bare frame structures was less than the suggested $R$ value $(=5)$ in the IS 1893 (2002) code [7]. Maheri and Akbari [8] evaluated the R factor of reinforced concrete buildings for steel X-braced and knee-braced systems. The $\mathrm{R}$ factor was evaluated using pushover analyses of three different frame systems viz., un-braced RC frame, X-braced RC frame, and knee braced RC frame of different heights and configurations. The authors analyzed three models of 4, 8, and 12 stories using the Drain 2DX software. They concluded that the value of the response reduction factor reduces as the height of frame increases. Furthermore, the average value of the response reduction factor of the twelve-story building for all ductility demands is 8.32 and 10.85 for the X-braced frame and knee-braced frame respectively, while for the unbraced moment resisting frame, it is 6.77. The behavior of the average $R$ value for the four- and eight-story buildings with different bracing systems is the same as 
the twelve-story building [8]. Goud and Pradeep Kumar [9] worked on the evaluation of the response reduction factor of reinforced concrete buildings. They designed a 5-story building for all seismic zones considering the ductile and non-ductile detailing provisions. The authors concluded that the computed average $\mathrm{R}$ value for seismic zones IV and V is 4.75, which is less than the given R value (=5) in the IS 1893:2002 [9]. Smyrou et al. [10] described the implementation of inelastic infill panel element for masonry infill panel in the SeismoStruct program. They compared the analytical results with the experimental values obtained from the pseudo dynamic test and also defined a characteristic value for material and geometrical properties of the infill [10]. From the analytical study, the value of $R$ increases when the infill is considered in the frame, so the $R$ value is sensitive to the material and geometrical configuration of the structure. The response reduction factor R significantly decreases by considering the opening in masonry infills as well as the seismic zone increases. In addition, this $\mathrm{R}$ factor reduces gradually as the height of the structure increases. The evaluated $\mathrm{R}$ factor based on the "Miranda and Bertero relationship" (1994) [11] is the most realistic as compared to other methods [6,12-17]. The failure pattern of a reinforced concrete structure is an important aspect to be assessed. Many researchers have worked on the failure pattern of the RC frames in several ways. The material strain limit approach is the newly developed and most realistic to identify the damage of the reinforced concrete structures. This approach will help to get information regarding the actual damage in the materials of RC structures [16-18]. Reliability analysis of RC structures is very important because of the consideration of uncertainties as an important dimension of the performance-based earthquake engineering $[19,20]$ which accounts for uncertainties in modeling and design. The present study attempts to evaluate the actual response reduction factor $(\mathrm{R})$ for $\mathrm{RC}$-infilled frames incorporating two different infill scenarios viz., semi-interlocked and un-reinforced masonry infills considering the effects of a lintel beam. Similarly, we present a comparison between the values obtained from numerical analyses with the codal provisions.

\section{Methodology}

\subsection{Adaptive Pushover Analysis}

Pushover analysis is generally used to quantify the nonlinear response of structures. Adaptive pushover analysis is an advancement of pushover analysis in which the applied load is updated at every step of the analysis. Adaptive pushover analysis is one of the significant alternative solutions for nonlinear dynamic analysis of structures. In multistory structures, ignoring the effect of higher modes is one of the limitations of such approaches. In this context, Kalkan and Kunnath [21] and Gupta and Kunnath [22] highlighted the significance of considering the higher mode effects depending on the adaptive pushover procedures, which include the increasing variation in the dynamic properties such as time period, frequency, etc. Antoniou and Pinho [23] employed a force-based adaptive pushover analysis in which the lateral load is continuously revised at every single step during the eigenvalue analysis. In this advanced static analysis method, the spectral amplification part is also important for updating the load vectors. As per the literature for the adaptive pushover case, one can introduce the record of earthquake ground motion and define the level of damping. In the present study, the acceleration time-history of the Chi-Chi earthquake (Taiwan, date: 20 September 1999) as shown in Figure 2 is used for analysis. 


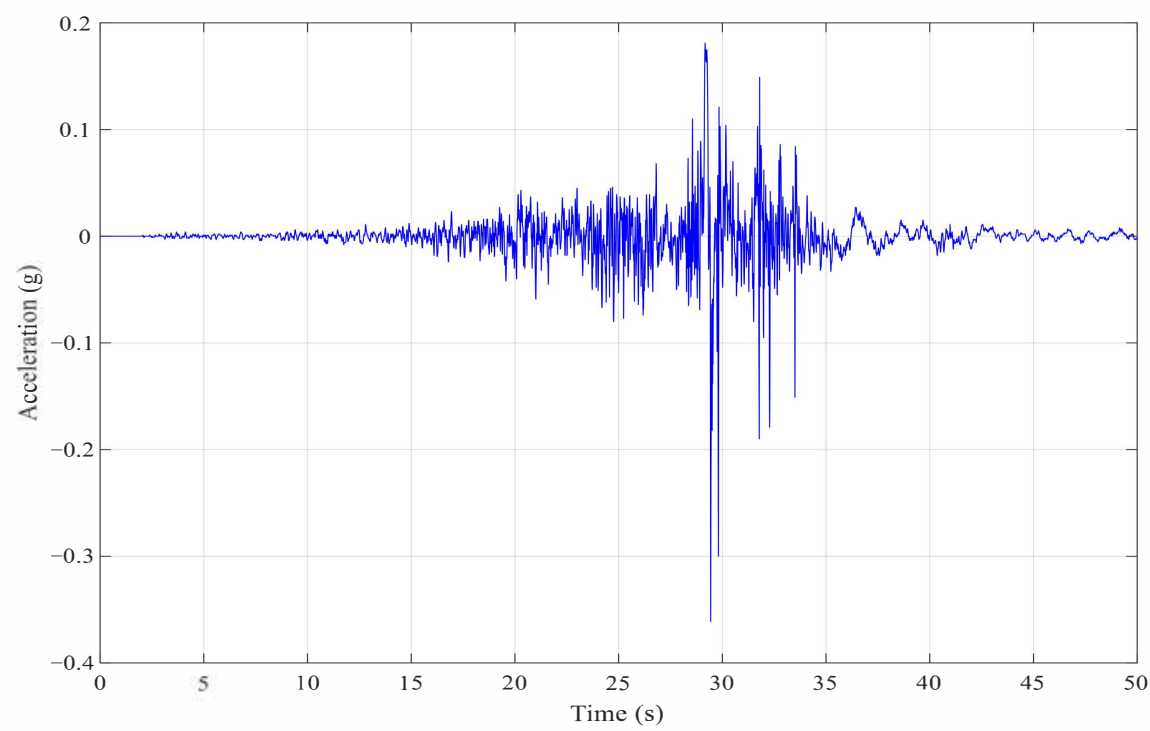

Figure 2. Acceleration time history of the Chi-Chi earthquake [24].

The evaluation of the response reduction factor is based on the adaptive pushover analysis. The $\mathrm{R}$ factor is generally used to minimize elastic response to inelastic response of structures as shown in Figure 3. The R factor mainly depends on three factors, i.e., ductility, overstrength, and redundancy factor, and it is expressed as:

$$
\mathrm{R}=\mathrm{R}_{\mathrm{d}} \times \mathrm{R}_{\mathrm{O}} \times \mathrm{R}_{\mathrm{R}}
$$

where $R$ is the response reduction factor, $R_{d}$ is the ductility reduction factor, $R_{O}$ is the overstrength factor, and $R_{R}$ is the redundancy factor. However, according to the BIS (Bureau of Indian Standards) code provisions [16-18,25], it is mathematically represented as:

$$
2 R=R_{d} \times R_{O}
$$

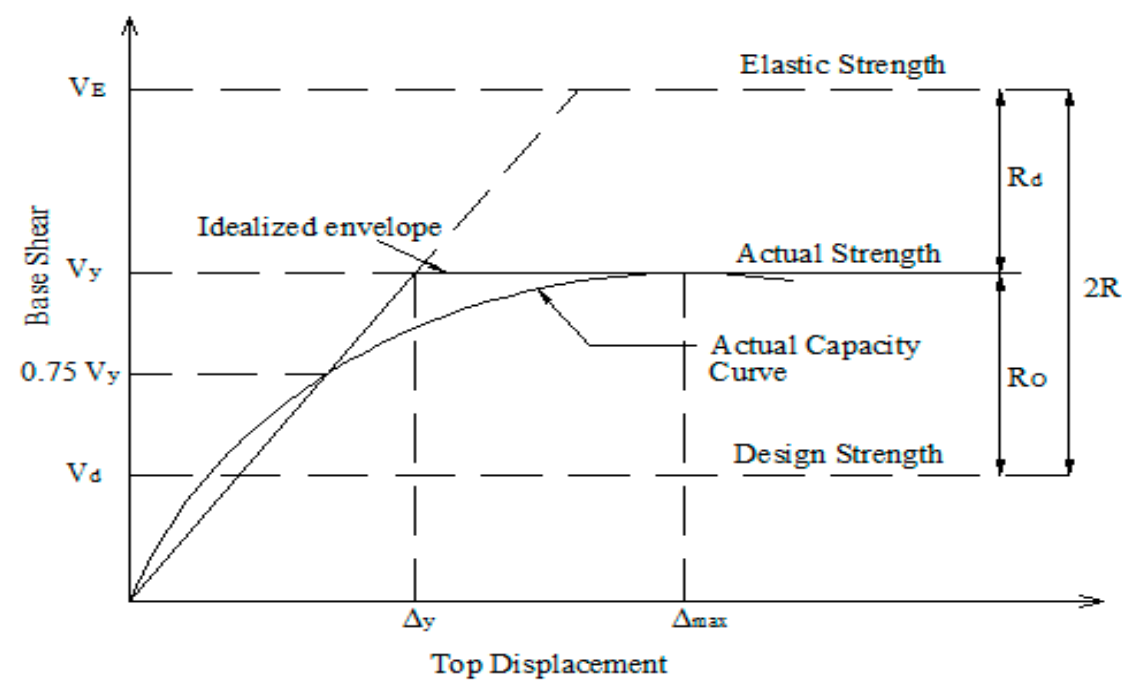

Figure 3. Interrelation between response reduction factor, over-strength, and ductility reduction factor [25].

As per the ATC-19 [26], the parameters such as the ductility reduction factor and the over-strength factor result in the response reduction factor. The ductility reduction factor measures the global nonlinear response (i.e., inelastic response) of a structure. It mainly 
depends on the ductility and fundamental time period of any structure. The displacement ductility is expressed as:

$$
\mu=\frac{\Delta_{\max }}{\Delta_{y}}
$$

where $\Delta_{\max }$ is the maximum displacement corresponding to peak base shear of pushover curve, and $\Delta_{y}$ is the yield displacement, calculated by reduced stiffness method [27]. In this study, the $R-\mu-T$ relationships proposed by Newmark and Hall [28] are used to evaluate $R_{d}$ as follows:

$$
\begin{gathered}
\text { If (time period }<0.2 \mathrm{~s} \text { ) then } R_{d}=1 \\
\text { If }(0.2 \mathrm{~s}<\text { time period }<0.5 \mathrm{~s}) \text { then } \mathrm{R}_{\mathrm{d}}=(2 \mu-1)^{1 / 2} \\
\text { If (time period }>0.5 \mathrm{~s}) \text { then } \mathrm{R}_{\mathrm{d}}=\mu
\end{gathered}
$$

The overstrength factor measures the reserved strength present in a structure. The main sources of overstrength factor are: (i) material strength, (ii) load factors and their combination, (iii) participation of nonstructural elements such as infill walls, and (iv) redundancy. It may be expressed as:

$$
\mathrm{R}_{\mathrm{O}}=\frac{V_{y}}{V_{d}}
$$

where $V_{y}$ is the ideal yield base shear and $V_{d}$ is the design base shear.

The redundancy is usually defined as the gap between the local yield point to the global yield point of a structure. Any building should have a high degree of redundancy for lateral resistance. In this study, the redundancy factor is incorporated into the overstrength factor. The BIS (Bureau of Indian Standards) code [29] recommends the response reduction factor to be 3 for ordinary moment resisting frame (OMRF) and 5 for special moment resisting frame (SMRF).

\subsection{Materials Strain Limit Approach}

Analysts and engineers must be capable of identifying the instants at which different performance limit states (e.g., structural damage) are reached. This can be efficiently carried out in SeismoStruct software [30] through the definition of performance criteria, whereby the attainment of a given threshold value of material strain is monitored during the analysis of a structure. Material strains usually constitute the best parameter for the identification of the performance state of a given structure when compared with other existing methods. It is possible in the SeismoStruct program because in this software, the distributed inelasticity (i.e., realistic phenomena) is given to each structural member so it is easy to identify the actual damage phenomena based on the materials in a structure.

To check the damage patterns of the structures, the performance criteria based on material strain used in the present numerical simulation are (1) yield strain limit for steel: 0.0025 , (2) crushing strain limit for unconfined concrete: 0.0035 , (3) crushing strain limit for confined concrete: 0.008 , and (4) fracture strain limit for steel: 0.06 [16-18].

\section{Model Description}

For this study, a 4-story RC building having symmetrical plan of 3-bay frames in $\mathrm{X}$ and $\mathrm{Y}$ directions with bay span of $4 \mathrm{~m}$ and floor height of $3 \mathrm{~m}$ is considered as per the current construction practice in India. The building is situated in seismic zone IV and is designed for lateral seismic load using the equivalent static method as per the IS 1893(Part-1):2016 code [29]. The foundation of the building is considered a rigid foundation. The building was modeled in the SeismoStruct program [30]. Five models have studied for comparing the performance of RC frame structures with lintel beam and infill opening is considered to assure realistic practical models. The models are as follows: (1) bare frame with lintel beam in both directions, (2) open ground story RC-URM infilled frame with lintel beam in both directions, (3) open ground story RC-SIM infilled frame with lintel beam in both directions, (4) full RC-URM infilled frame with lintel beam in both directions, and (5) 
full RC-SIM infilled frame with lintel beam in both directions. The five models of the building are shown in Figures 4 and 5 together with the plan of the building, where the global coordinates $\mathrm{X}$ and $\mathrm{Y}$ are in the planar directions and $\mathrm{Z}$ is in the vertical direction. $\mathrm{A}$ summary of material and sectional properties is presented in Table 1.

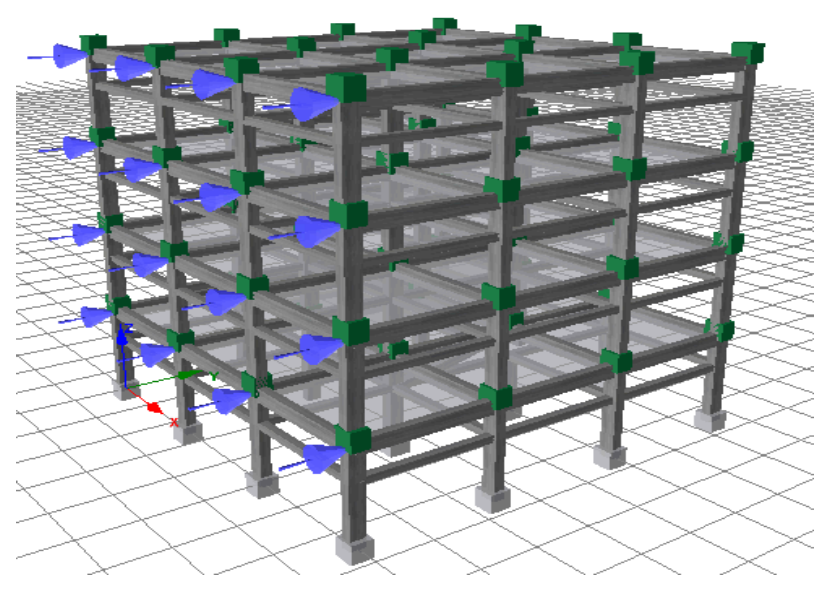

(a)

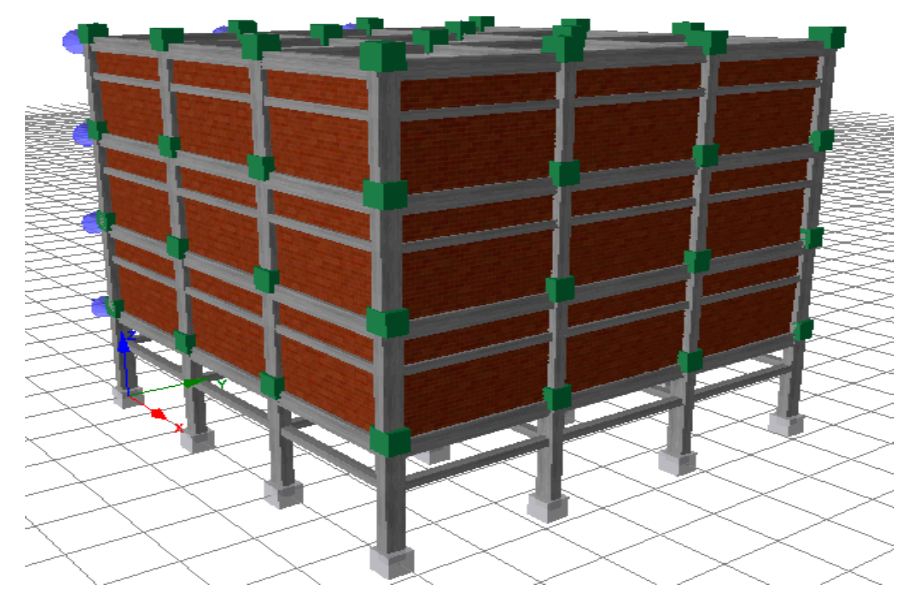

(c)

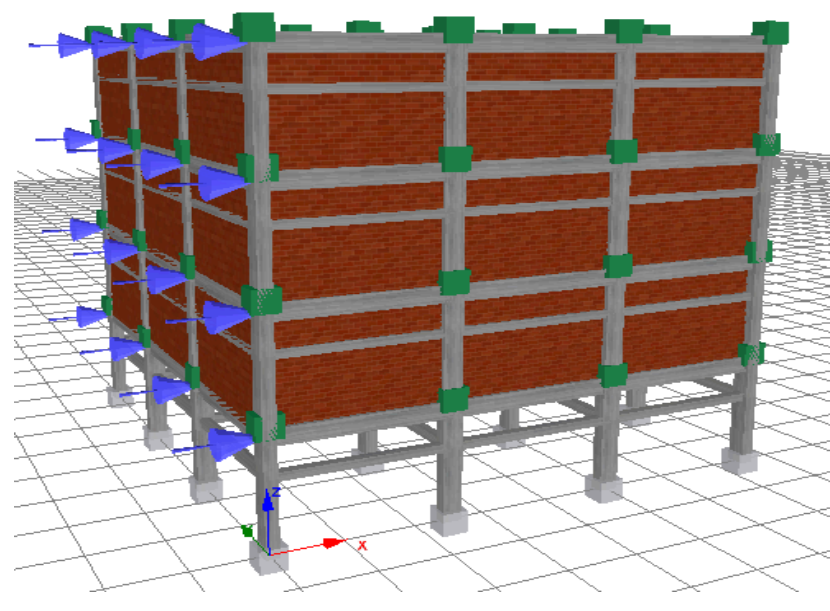

(b)

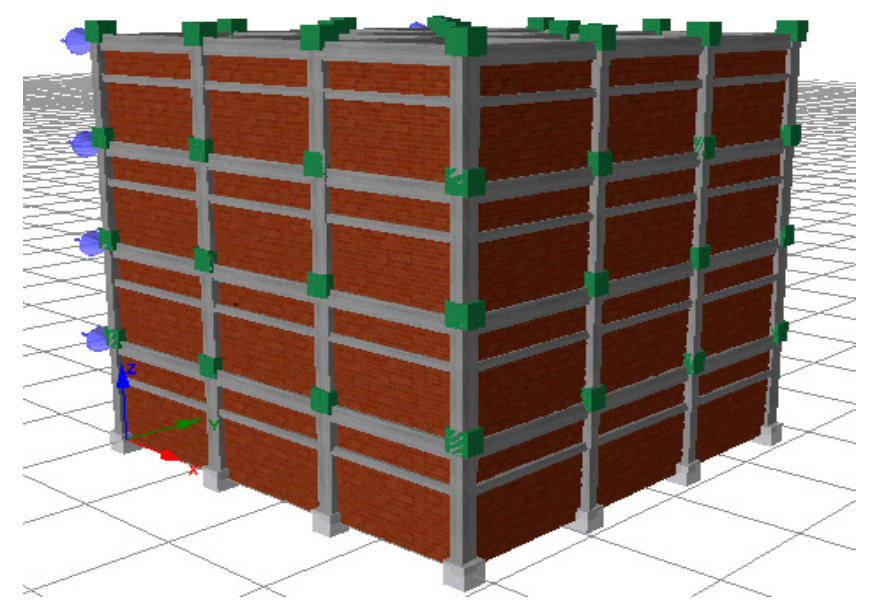

(d)

Figure 4. Three-dimensional (3D) finite element models of the case study building: (a) bare frame with lintel beam; (b) open ground reinforced concrete (RC)-URM infill with lintel beam; (c) open ground RC-SIM infill with lintel beam; (d) full RC-URM infill with lintel beam. 


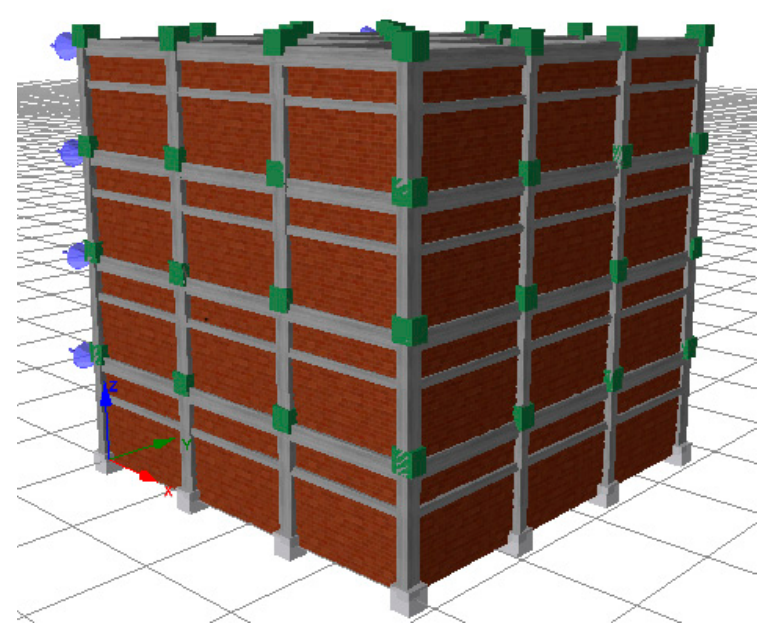

(a)

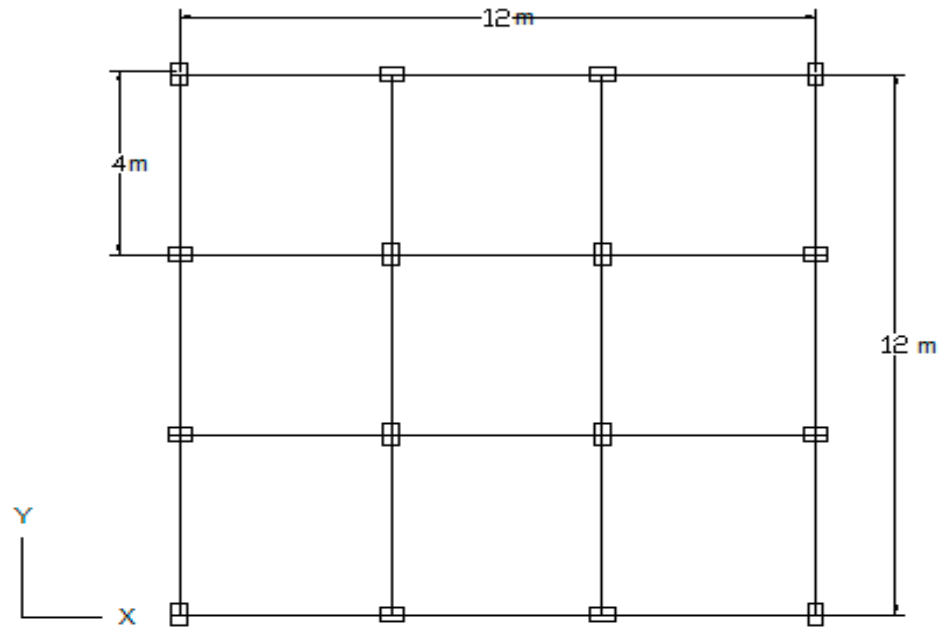

(b)

Figure 5. (a) 3D model of full RC-SIM infill with lintel beam; (b) Plan of the case study building.

Table 1. Structural details of the building.

\begin{tabular}{cc}
\hline Type of Structure & Special Moment Resisting Frames \\
\hline Number of stories & 4 \\
Seismic zone & IV \\
Floor height & $3 \mathrm{~m}$ \\
Bay length & $4 \mathrm{~m}$ along X and Y direction \\
Infill wall & SIM-110 mm and URM-113 mm \\
Compressive strength & SIM-2.5 MPa, URM-5.5 MPa \\
Modulus of elasticity & SIM-2500 MPa, URM-4000 MPa \\
Type of soil & Medium stiff soil \\
Column size (mm) & $300 \times 450$ \\
Beam size (mm) & $250 \times 450$ \\
Lintel Beam size (mm) & $230 \times 230$ \\
Slab depth (mm) & 150 \\
Live load (kN/m $\left.{ }^{2}\right)$ & 3 \\
& reinforcement (yield strength of steel is 415 \\
Material & MPa) \\
& $5 \%$ \\
Damping in structure & 1.2 \\
Importance factor (I) & 5 \\
Response reduction factor $(\mathrm{R})$ & 2.5 \\
$\frac{S_{a}}{g}$ & $7805.76 \mathrm{kN}$ \\
\hline Seismic weight $(\mathrm{W})$ & compressive strength is $25 \mathrm{MPa})$ and Fe- 15 \\
\hline
\end{tabular}

The total seismic weight of the five models has been calculated manually and the design base shear has also been evaluated according to the Indian code IS 1893 Part1:2016 as:

$$
V_{d}=\frac{Z}{2} \frac{I}{R} \frac{S_{a}}{g} \times W
$$

where $V_{d}$ is the design base shear, $Z$ is the seismic zone factor, $I$ is the importance factor, $\left(S_{a} / g\right)$ is the spectral acceleration coefficient, $R$ is the response reduction factor, and $W$ is the seismic weight of the structure. The design base shear is estimated to be $562.01 \mathrm{kN}$.

For this study, the strut curve and shear curve parameters were taken from the experimental study [3], and the geometrical parameters viz., the width of a strut, area of a 
strut, horizontal offset, vertical offset, etc., were calculated based on the structural members as shown in Table 2.

Table 2. Input parameters of SIM infill and URM infill panel [3].

\begin{tabular}{|c|c|c|}
\hline Parameters & SIM Infill Values & URM Infill Values \\
\hline Panel thickness & $110 \mathrm{~mm}$ & $113 \mathrm{~mm}$ \\
\hline Out-of-plane failure drift & $7.6 \%$ & $0.50 \%$ \\
\hline Strut area, $\mathrm{A}_{1}$ & $31,380.25 \mathrm{~mm}^{2}$ & $30,647.86 \mathrm{~mm}^{2}$ \\
\hline Residual area, $\mathrm{A}_{2}$ & $60 \%$ & $50 \%$ \\
\hline Equivalent contact length, $\mathrm{h}_{\mathrm{z}}$ & $25.17 \%$ & $22.18 \%$ \\
\hline Horizontal offset, $x_{o i}$ & $5.62 \%$ & $5.62 \%$ \\
\hline Vertical offset, $y_{o i}$ & $7.50 \%$ & $7.50 \%$ \\
\hline Proportion of stiffness assigned to shear, $\gamma_{\mathrm{s}}$ & $70.00 \%$ & $5.00 \%$ \\
\hline Specific weight, $\gamma$ & $23.5 \mathrm{kN} / \mathrm{m}^{3}$ & $23.5 \mathrm{kN} / \mathrm{m}^{3}$ \\
\hline Elastic modulus, $\mathrm{E}_{\mathrm{m}}$ & $2500 \mathrm{MPa}$ & $4000 \mathrm{MPa}$ \\
\hline Compressive strength, $\mathrm{f}_{\mathrm{m} \theta}$ & $2.5 \mathrm{MPa}$ & $5.5 \mathrm{MPa}$ \\
\hline Tensile strength, $\mathrm{f}_{\mathrm{t}}$ & $0.0 \mathrm{MPa}$ & $0.575 \mathrm{MPa}$ \\
\hline Strain at maximum stress, $\varepsilon_{\mathrm{m}}$ & 0.002 & 0.0012 \\
\hline Ultimate strain, $\varepsilon_{\text {ult }}$ & 0.024 & 0.024 \\
\hline Closing strain, $\varepsilon_{\mathrm{cl}}$ & 0.004 & 0.003 \\
\hline Strut area reduction strain, $\varepsilon_{1}$ & 0.0006 & 0.0003 \\
\hline Residual strut area strain, $\varepsilon_{2}$ & 0.001 & 0.0006 \\
\hline Initial unloading stiffness factor, $\gamma_{\text {un }}$ & 2.5 & 1.7 \\
\hline Strain reloading factor, $\alpha_{\text {re }}$ & 0.2 & 0.2 \\
\hline Strain inflection factor, $\alpha_{\mathrm{ch}}$ & 0.7 & 0.7 \\
\hline Complete unloading strain factor, $\beta_{\mathrm{a}}$ & 2 & 2 \\
\hline Stress inflection factor, $\beta_{\mathrm{ch}}$ & 0.9 & 0.9 \\
\hline Zero stress stiffness factor, $\gamma_{\text {plu }}$ & 1 & 1 \\
\hline Reloading stiffness factor, $\gamma_{\mathrm{plr}}$ & 1.5 & 1.1 \\
\hline Plastic unloading stiffness factor, $\mathrm{e}_{\mathrm{x} 1}$ & 3 & 3 \\
\hline Repeated cycle strain factor, $\mathrm{e}_{\mathrm{x} 2}$ & 1 & 1 \\
\hline Shear bond strength, $\tau_{0}$ & $0.1 \mathrm{MPa}$ & $0.3 \mathrm{MPa}$ \\
\hline Friction coefficient, $\mu$ & 1.2 & 0.7 \\
\hline Maximum shear resistance, $\tau_{\max }$ & $1 \mathrm{MPa}$ & $1 \mathrm{MPa}$ \\
\hline Reduction shear factor, $\alpha_{\mathrm{s}}$ & 1.5 & 1.5 \\
\hline
\end{tabular}

3.1. Calculation of the Geometrical Parameters of the Infill Wall

Bay length $=4 \mathrm{~m}$

Story height $=3 \mathrm{~m}$

Thickness of SIM infill $=110 \mathrm{~mm}$

Thickness of URM infill $=113 \mathrm{~mm}$

Infill panel net length $=4-0.45=3.55 \mathrm{~m}$

Infill panel net height $=3-0.45=2.55 \mathrm{~m}$

Diagonal length $\left(d_{\text {inf }}\right)=4.37 \mathrm{~m}$

The equivalent width of strut can be depicted as:

$$
\lambda_{\mathrm{h}}=\mathrm{h} \sqrt[4]{\frac{E_{\text {inf }} t \sin 2 \varnothing}{4 E_{c} I_{c} h_{\text {inf }}}}(\text { Dimensionless parameters })
$$

This yields $\lambda_{\mathrm{h}}=2.08(\mathrm{SIM}), \lambda_{\mathrm{h}}=2.36(\mathrm{URM})$

$$
\begin{aligned}
\mathrm{Z} & =\frac{\pi}{2 \lambda_{\mathrm{h}}} \times \mathrm{h} \\
h_{z} & =\frac{z}{3 h_{\text {inf }}} 100
\end{aligned}
$$

Thus, $h_{z}=25.17 \%(\mathrm{SIM}), h_{z}=22.18 \%(\mathrm{URM})$ 
For the evaluation of the equivalent contact length of double strut, Stafford Smith [31] adopted the value as $\mathrm{Z} / 3$ and width of strut is calculated as:

$$
\text { Width of strut }=0.175 d_{\text {inf }}\left(\lambda_{h}\right)^{-0.4}
$$

Thus, width of strut $=570.55 \mathrm{~mm}(\mathrm{SIM})$, width of strut $=542.44 \mathrm{~mm}(\mathrm{URM})$

Width of strut with opening in infill $=285.27 \mathrm{~mm}$ (SIM)

Width of strut with opening in infill $=271.22 \mathrm{~mm}$ (URM)

Area of strut for infill $=b_{w} \times \mathrm{t}=31380.25 \mathrm{~mm}^{2}$ (SIM)

Area of strut for infill $=b_{w} \times \mathrm{t}=30647.86 \mathrm{~mm}^{2}(\mathrm{URM})$

Horizontal offset $\left(X_{\mathrm{oi}}\right)=\frac{0.225}{4} \times 100=5.62 \%$ (SIM and URM infill)

Vertical offset $\left(\mathrm{Y}_{\mathrm{oi}}\right)=\frac{0.225}{3} \times 100=7.5 \%$ (SIM and URM infill).

\subsection{Material Parameters}

\subsubsection{Concrete Model}

This model is a uniaxial nonlinear constant confinement model. The confinement effects provided by the lateral transverse reinforcement were incorporated as suggested by Mander et al. [32,33] in which a constant confining pressure is assumed throughout the entire stress-strain range.

\subsubsection{Steel Model}

This is a uniaxial steel model initially programmed by Yassin [34] based on the stressstrain relationship proposed by Menegotto and Pinto [35]. Its employment should be confined to the modeling of reinforced concrete structures, particularly those subjected to complex loading histories. Isotropic hardening is considered in this model. This model can be useful for the ribbed as well as smooth rebars.

\subsubsection{Infill Panel Element}

Infill panel element is represented by four axial struts and two shear springs, as shown in Figure 6. Four nodded panel masonry elements were developed by the Crisafulli [36]. It accounts for the compressive and shear behavior of masonry separately and adequately represents the hysteretic response. It shows the accuracy of the model to evaluate the nonlinear response of the structure. This model is also known as the double strut nonlinear cyclic model. The presence of an opening in infill will directly affect the structural integrity of the structure and the effect can be incorporated by minimizing the width (diagonal strut). The stiffness reduction factor [37] to consider the opening effect in the infill in numerical modeling is given by:

$$
\mathrm{W}_{\mathrm{do}}=\left(1-2.5 \mathrm{~A}_{\mathrm{r}}\right) \mathrm{W}_{\mathrm{d}}
$$

where $W_{d}$ is the width of the diagonal strut, $W_{d o}$ is the width of the diagonal strut with opening in infill, and $A_{r}$ is the ratio of the opening area to the face area of infill. Equation (11) is valid for openings in wall greater than $5 \%$ and lesser than $40 \%$. In this paper, the openings in infill are considered $1.2 \mathrm{~m} \times 1.2 \mathrm{~m}$ and $1 \mathrm{~m} \times 1 \mathrm{~m}$, which means approximately $20 \%$ area of infill is considered the opening area. 


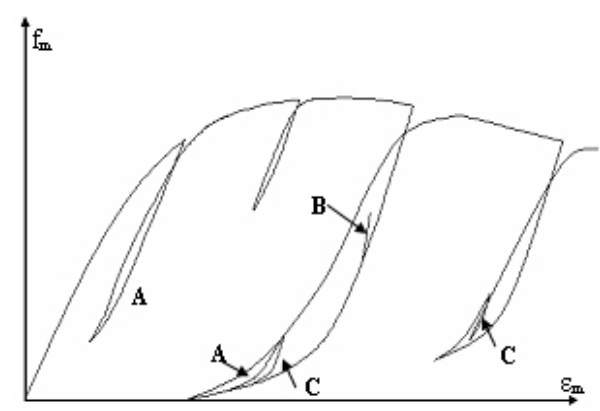

(a)

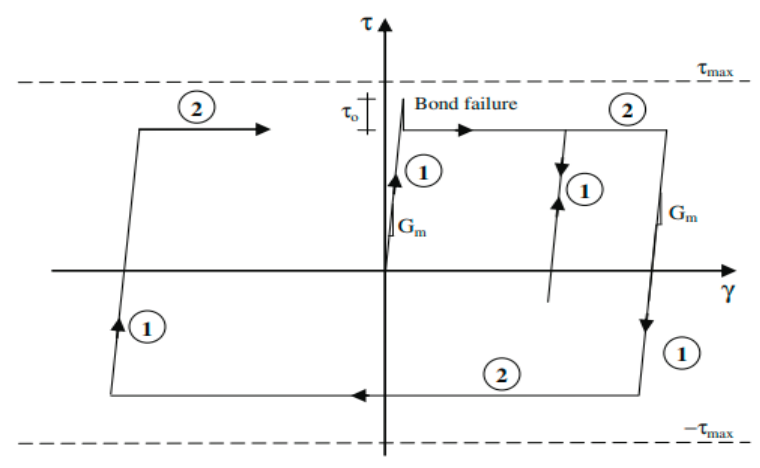

(b)
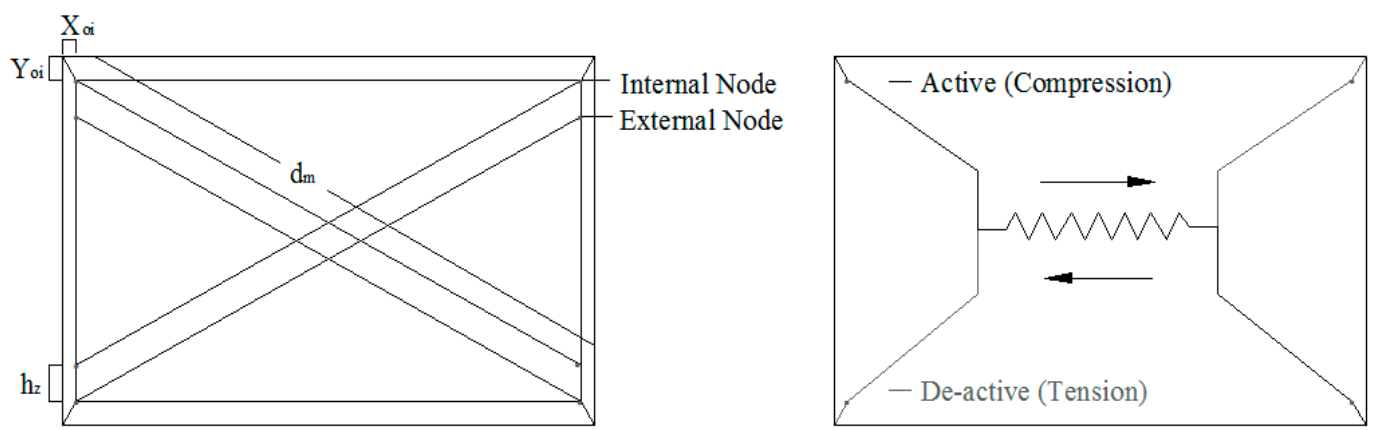

(c)

Figure 6. (a) Masonry strut hysteresis; (b) shear cyclic relationship; and (c) infill panel element configuration [36].

In this study, the distributed inelasticity is used to define the nonlinearity of structural members in the SeismoStruct program [30]. This distributed inelasticity is provided to the structural members as follows: the member was divided into three sections (top, bottom, and middle) and each section disintegrated into 150 fibers. Therefore, this method gives more accurate nonlinear behavior as compared to concentrated inelasticity. The dimension and reinforcement of the structural members are as per the IS 1893 (Part-1): 2016 and IS 13920: 2016 code [38]. The structural members detailing is shown in Figure 7 and the dimensions of structural members are presented in Table 3.

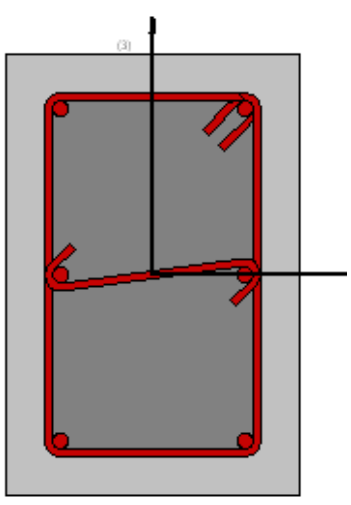

(a)

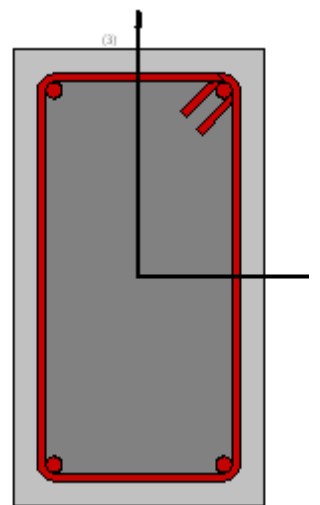

(b)

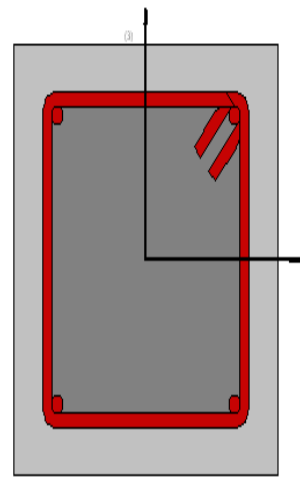

(c)

Figure 7. Structural detailing of: (a) column; (b) beam; and (c) lintel beam. 
Table 3. Dimensions and detailing of the structural members.

\begin{tabular}{|c|c|c|c|}
\hline Structural Member & Size $(\mathrm{mm})$ & Main Reinforcement & $\begin{array}{c}\text { Shear } \\
\text { Reinforcement }\end{array}$ \\
\hline $\begin{array}{l}\text { All columns } \\
\text { of the building }\end{array}$ & $300 \times 450$ & $\begin{array}{l}4 \text { nos. of } 16 \mathrm{~mm} \text { dia. at a corner and } \\
\text { two nos. of } 16 \mathrm{~mm} \text { on the longer side }\end{array}$ & $\begin{array}{l}8 \mathrm{~mm} \mathrm{dia.} \\
\text { at } 100 \mathrm{~mm} \mathrm{c} / \mathrm{c}\end{array}$ \\
\hline $\begin{array}{l}\text { All beams } \\
\text { of the building }\end{array}$ & $250 \times 450$ & $\begin{array}{l}2 \text { nos. of } 16 \mathrm{~mm} \text { diameter } \\
\text { at top and bottom }\end{array}$ & $\begin{array}{l}8 \mathrm{~mm} \mathrm{dia.} \\
\text { at } 100 \mathrm{~mm} \mathrm{c} / \mathrm{c}\end{array}$ \\
\hline $\begin{array}{l}\text { All lintel beams } \\
\text { of the building }\end{array}$ & $230 \times 230$ & $\begin{array}{l}2 \text { nos. of } 10 \mathrm{~mm} \text { diameter } \\
\text { at top and bottom }\end{array}$ & $\begin{array}{l}8 \mathrm{~mm} \mathrm{dia.} \\
\text { at } 200 \mathrm{~mm} \mathrm{c} / \mathrm{c}\end{array}$ \\
\hline
\end{tabular}

\section{Results and Discussion}

\subsection{Pushover Curves}

The utilization of nonlinear static analysis came into practice in the $1970 \mathrm{~s}$ but the importance of this pushover analysis has been realized primarily in the last two decades. The parameters such as ductility, $\mathrm{R}$ factor, etc. can be obtained from the pushover curves. Another important issue is the significance of the infill that plays a vital role in the seismic performance of RC frames. Similarly, the capacity of the structure can also be estimated using the pushover curves. The base shear is lower in the bare frame as compared to all other frames due to the absence of masonry infills as shown in Figure 8. As per Figure 8, the full RC-SIM infilled frames have a maximum capacity to resist the lateral load when compared to the full RC-URM infilled frames due to their inherent material and geometrical properties. The base shear of the open ground story RC-infilled frame with lintel beam slightly increases as compared to the bare frame as shown in Figure 8.

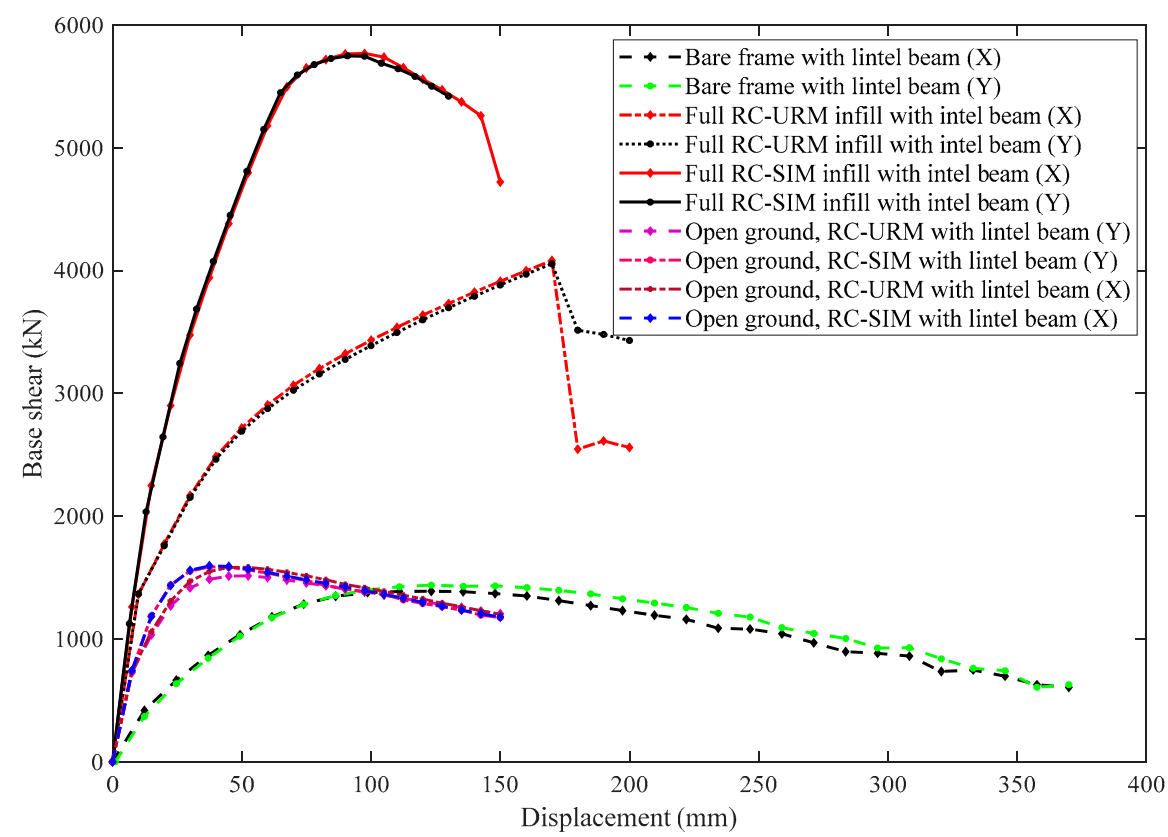

Figure 8. Comparison of pushover curves for various analysis scenarios.

\subsection{Base Shear}

As per Figure 9a, the base shear was lower in the bare frame when compared to the fully RC-infilled frames. Due to the symmetry of the building in both directions, there was a small variation in the base shears of the different models. On average, the base shear increased by $41.53 \%$ in full RC-SIM infilled frame with lintel beam when compared to full RC-URM infilled frame with lintel beam because the SIM panel dissipates more energy than the URM panel. On average, the base shear in the full RC-SIM infilled frame with lintel beam increased by 4.07 times the bare frame with lintel beam. There was a slight 
variation in the case of open ground story RC-SIM infilled frame and open ground story RC-URM infilled frame with lintel beam.
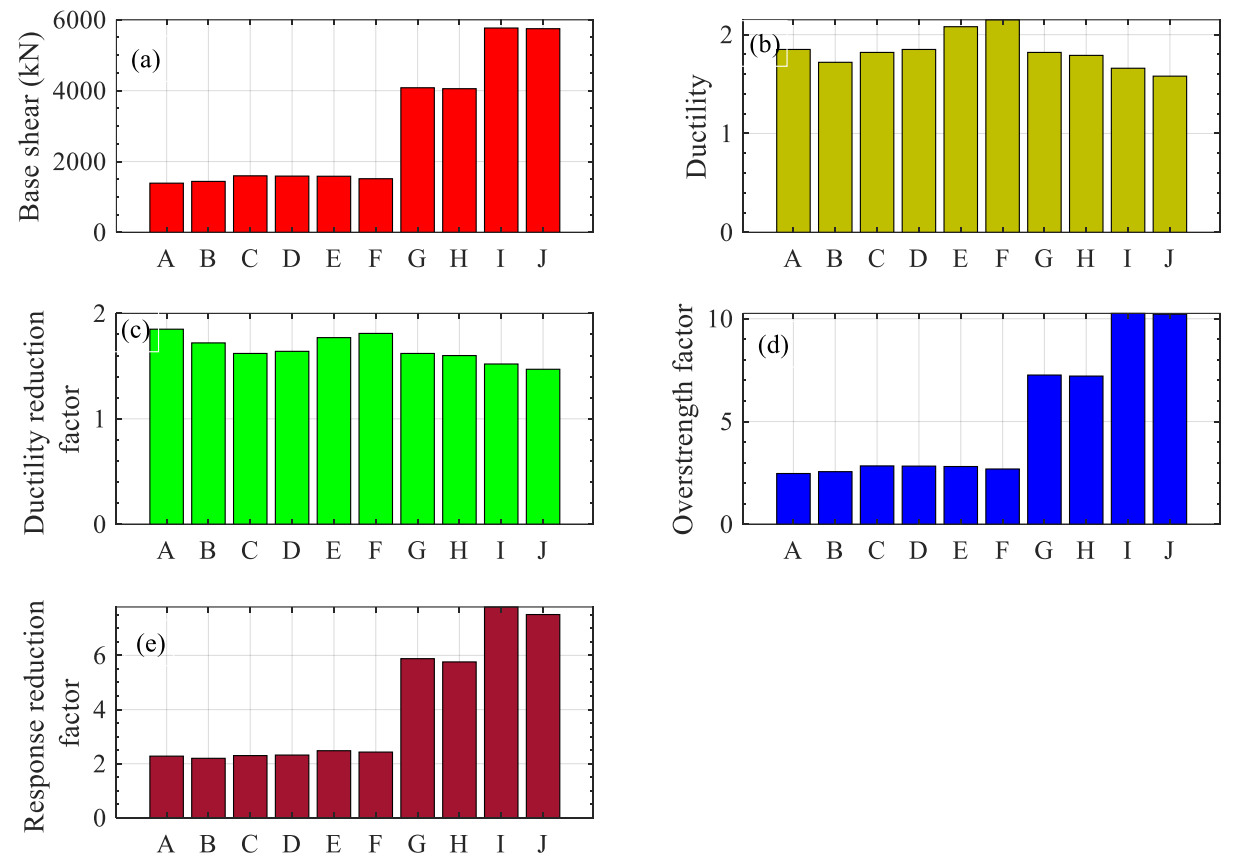

Figure 9. Comparisons of performance parameters for various analysis scenarios: (a) Base shear; (b) ductility; (c) ductility reduction factor; (d) overstrength factor; and (e) response reduction factor. In this figure, the analysis scenarios represented by alphabets are: $\mathbf{A}=$ bare frame with intel beam $(\mathrm{X})$; $\mathbf{B}=$ bare frame with lintel beam (Y); C = open ground story, RC-SIM infill with lintel beam (X); D = open ground story, RC-SIM infill with lintel beam (Y); E = open ground story, RC-URM infill with lintel beam $(\mathrm{X}) ; \mathbf{F}=$ open ground story, RC-URM infill with lintel beam (Y); G = Full RC-URM infill frame with lintel beam (X); H = Full RC-URM infill with lintel beam (Y); I = Full RC-SIM infill frame with lintel beam (X); J = Full RC-SIM infill frame with lintel beam (Y).

\subsection{Ductility}

As shown in Figure 9b, the average ductility was higher in the open ground story RC-URM infilled frame with a lintel beam when compared to all other frames due to the absence of infills at ground level. The average ductility increased by $2.52 \%$ and $18.20 \%$ in the open ground story RC-SIM infilled frame with lintel beam and the open ground story RC-URM infilled frame with lintel beam, respectively, when compared to the bare frame with lintel beam, due to the greater initial stiffness of the open ground story RC-infilled frame as compared to the bare frame, so the yield point of the open ground story RC-infilled frame was less as compared to the bare frame. Moreover, the average ductility increased by $17.22 \%$ and $12.96 \%$ in the open ground story RC-URM infilled frame with lintel beam and the open ground story RC-SIM infilled frame with lintel beam, respectively, when compared to the full RC-URM infilled frame with lintel beam and the full RC-SIM infilled frame with lintel beam due to the sudden change in stiffness at ground level and it allows maximum drift. On average, ductility increased by $11.11 \%$ in the full RC-URM infilled frame with lintel beam when compared to the full RC-SIM infilled frame with lintel beam due to its material property.

\subsection{Ductility Reduction Factor}

The ductility reduction factor was evaluated on the basis of the ductility and time period. As shown in Figure 9c, the average ductility reduction factor was almost the same for the ductility in the bare frame only due to the long period of the structure. In the present study, the reduced stiffness method was used to calculate ductility, so the ductility 
factor of the RC-infilled frame is closer to the bare frame. Generally, in the experimental study, we observed a significant difference in ductility factors between the bare frame and RC-infilled frames due to the use of the first yield point definition instead of using the reduced stiffness method [27]. On average, the ductility reduction factor increased by $8.05 \%$ in the full RC-URM infilled frame with lintel beam when compared to the full RC-SIM infilled frame with lintel beam. Similarly, the ductility reduction factor increased by $9.81 \%$ in the open ground story RC-URM infilled frame with lintel beam when compared to the open ground story RC-SIM infilled frame with lintel beam. There was no grave difference between the ductility reduction factor in the open ground story RC-URM infilled frame with lintel beam and the bare frame with lintel beam.

\subsection{Overstrength Factor}

As shown in Figure 9d, the overstrength factor was higher in the full RC-SIM infilled frame with a lintel beam when compared to all other frames because of the shear sliding mechanism in the semi-interlocked brick units that resulted in greater energy dissipation. On average, the overstrength factor increased by $41.63 \%$ in the full RC-SIM infilled frame with lintel beam as compared to the full RC-URM infilled frame with lintel beam. The overstrength factor is always low in the bare frame because of the absence of infills in the frame. The overstrength factor was 1.03 times greater in the open ground story RC-SIM infilled frame with lintel beam when compared to the open ground story RC-URM infilled frame with lintel beam. Furthermore, the average overstrength factor is 4.07 times greater in the full RC-SIM infilled frame with lintel beam when compared to the bare frame with lintel beam.

\subsection{Response Reduction Factor}

As per Figure 9e, the response reduction factor is higher in the full RC-SIM infilled frame with a lintel beam when compared to all other frames. In this study, the R factor was more dependent on the overstrength factor so the behavior of both factors for all frames was quite similar as per Figure 9d,e. The $\mathrm{R}$ factor increased on average (average value in $\mathrm{X}$ and $\mathrm{Y}$ direction) by $31.44 \%$ in the full RC-SIM infilled frame with a lintel beam when compared to the full RC-URM infilled frame with a lintel beam. The average R-factor of the full RC-SIM infilled frame with lintel beam and the full RC-URM infilled frame with lintel beam was $53 \%$ and $16.4 \%$ greater, respectively, when compared to the values recommended by the BIS (Bureau of Indian Standards) code. In addition, in the case of the bare frame with lintel beam, the average value of $R$ was $55.2 \%$ lower when compared to the BIS code recommendation. Notably, the results obtained by Alguhane et al. [5] highlight that the response reduction factor of the bare frame was less than the specified code value ( $\mathrm{R}$ factor 2.5 and overstrength factor 3, according to the Saudi Building Code SBC 301) by $18.4 \%$. However, including an infill wall in the frame system, the $\mathrm{R}$ factor was found to be increased by $82 \%$. Similarly, the over-strength factor was increased by $51.66 \%$ when compared to the codal provisions.

\subsection{Damage Patterns}

Generally, the failure mechanism in reinforced concrete structures is relevant to steel and concrete material only. In this study, we used the materials strain limit approach to identify the actual damage of the structure. Herein, the step-by-step failure stage is: (1) yielding of steel occurs, (2) crushing of unconfined concrete (i.e., spalling of cover concrete) occurs, (3) crushing of confined concrete (i.e., the core portion of concrete) occurs, and finally, (4) fracture of steel occurs. The above failure procedure is described based on the threshold damage limit state of materials. The threshold damage limit state of materials is as follows: strain at first yielding of steel, 0.0025; strain at first crushing of unconfined concrete, 0.0035 ; strain at first crushing of confined concrete, 0.008 ; and strain at first fracture of steel, 0.06 . 
As shown in Figure 10, the first yielding of steel occurred at base shear $1024.63 \mathrm{kN}$ and displacement $49.33 \mathrm{~mm}$ for the bare frame analysis scenario. The first crushing of unconfined concrete, i.e., spalling of cover concrete occurred at the base shear $1354.68 \mathrm{kN}$ and displacement $86.33 \mathrm{~mm}$. The first crushing of confined concrete, i.e., the core portion of concrete occurs at $1432.44 \mathrm{kN}$ and displacement $148.00 \mathrm{~mm}$. The first fracture point is present at the base shear $1327.71 \mathrm{kN}$ and displacement $197.33 \mathrm{~mm}$.

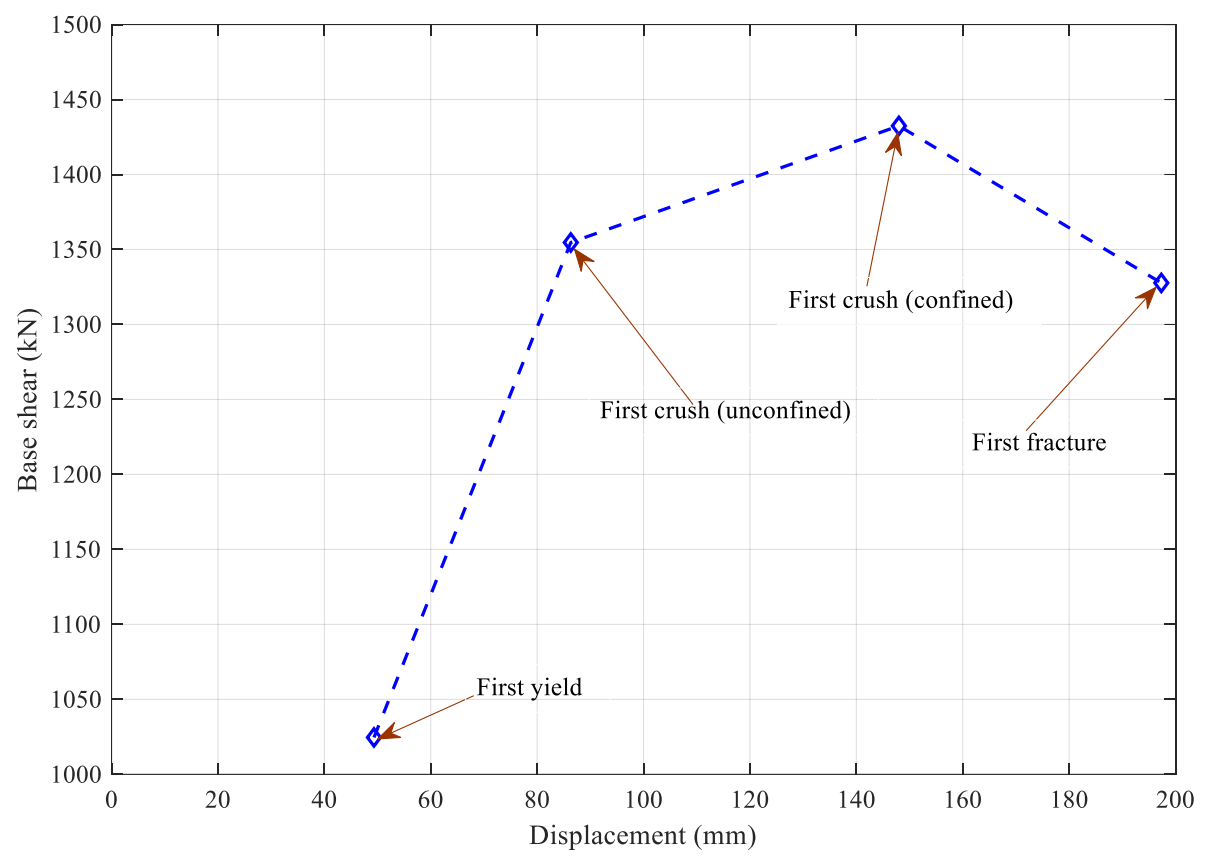

Figure 10. Damage pattern for bare frame analysis scenario.

As shown in Figure 11a, the first yielding of steel occurred at base shear $1435.68 \mathrm{kN}$ and displacement $22.50 \mathrm{~mm}$ for the open ground story RC-SIM infilled frame with lintel beam analysis scenario. The first crushing of unconfined concrete, i.e., spalling of cover concrete occurred at base shear $1596.26 \mathrm{kN}$ and displacement $37.50 \mathrm{~mm}$. The first crushing of confined concrete, i.e., the core portion of concrete occurred at the base shear $1482.01 \mathrm{kN}$ and displacement $75.00 \mathrm{~mm}$. The first fracture point was present at the base shear $1268.28 \mathrm{kN}$ and displacement $127.50 \mathrm{~mm}$.

Figure $11 \mathrm{~b}$ shows that the first yielding of steel occurred at the base shear $1310.16 \mathrm{kN}$ and displacement $22.50 \mathrm{~mm}$ for open ground story RC-URM infilled frame with lintel beam. The first crushing of unconfined concrete, i.e., spalling of cover concrete occurred at the base shear $1582.89 \mathrm{kN}$ and displacement $45.00 \mathrm{~mm}$. Similarly, the first crushing of confined concrete, i.e., the core portion of concrete occurred at the base shear $1482.85 \mathrm{kN}$ and displacement $82.50 \mathrm{~mm}$. The first fracture point occurred at the base shear $1262.86 \mathrm{kN}$ and displacement $135.00 \mathrm{~mm}$.

As shown in Figure 11c, the first yielding of steel occurred at base shear $3686.35 \mathrm{kN}$ and displacement $32.50 \mathrm{~mm}$ for full RC-SIM infilled frame with lintel beam. The first crushing of unconfined concrete, i.e., spalling of cover concrete occurred the base shear $5448.92 \mathrm{kN}$ and displacement $65.00 \mathrm{~mm}$. The first crushing of confined concrete, i.e., the core portion of concrete occurred at the base shear $5688.42 \mathrm{kN}$ and displacement $104.00 \mathrm{~mm}$.

As shown in Figure 11d, the first yielding of steel occurred at base shear $2464.45 \mathrm{kN}$ and displacement $40.00 \mathrm{~mm}$ for full RC-URM infilled frame with lintel beam. The first crushing of unconfined concrete, i.e., spalling of cover concrete occurred the base shear $3025.98 \mathrm{kN}$ and displacement $70.00 \mathrm{~mm}$. First crushing of confined concrete, i.e., the core portion of concrete occurred at the base $3790.96 \mathrm{kN}$ and displacement $140 \mathrm{~mm}$. The first fracture point occurred at the base shear $3430.45 \mathrm{kN}$ and displacement $200 \mathrm{~mm}$. 

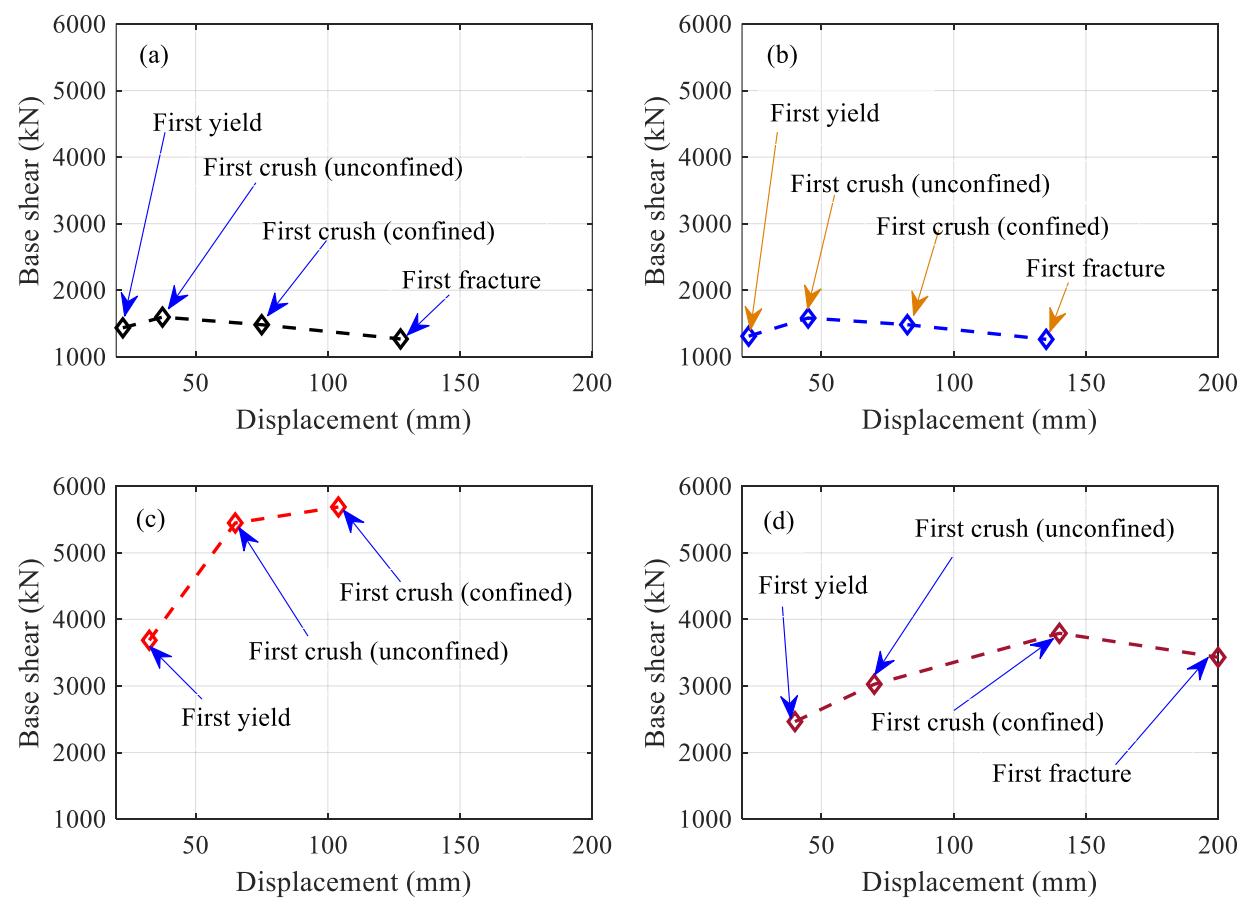

Figure 11. Damage pattern obtained for various damage scenarios: (a) open ground story RC-SIM infilled frame with lintel beam; (b) open ground story RC-URM infilled frame with lintel beam; (c) full RC-SIM infilled frame with lintel beam; and (d) full RC-URM infilled frame with lintel beam.

\section{Conclusions}

Based on the analysis of RC frame building with the combination of semi-interlocked masonry (SIM), unreinforced masonry (URM) infills, and lintel beam, this study assesses the variation in the seismic performance for several analysis scenarios. The performance parameters such as the response reduction factor, overstrength factor, ductility, etc. were compared for several scenarios using adaptive pushover analysis. The average base shear value was 1.41 times greater in the case of the full RC-SIM infilled frame with lintel beam when compared to the full RC-URM infilled frame with lintel beam. The average response reduction factor was 1.31 times greater in the full RC-SIM infilled frame with lintel beam when compared to the full RC-URM infilled frame with lintel beam because the SIM panels have the potential to dissipate more amount of energy due to the shear sliding mechanism in the brick units. The computed values of the response reduction factor $\mathrm{R}$ for bare frames with lintel beam obtained by adaptive pushover analysis of frames were smaller than the value suggested in the seismic code. Notably, after the incorporation of lintel beams in the frame, the computed values of the response reduction factor $\mathrm{R}$ for bare frames were less than the value recommended by IS 1893 (Part 1):2016. The computed values of the response reduction factor R for RC-infilled frames obtained from adaptive pushover analysis of frames were more than the value suggested in the IS 1893 (Part 1):2016. The over-strength factor was significantly influenced by the presence of infill in the frame. As a result, the response reduction factor of the RC-infilled frame was higher than the bare frame in a seismically active zone. The width of the strut for the infill decreased as the opening considered in the masonry infill and the overall capacity of the structure also decreased. The present study highlights that the combination of lintel beam and semi-interlocked masonry in the RC frame structure is more effective in a seismically active region than the unreinforced masonry frame structure due to material properties, geometrical shape, and structural configuration. Based on the findings of this work, we should consider the infill in the frame structure to enhance the structural integrity of the structure. The present study highlights that the response reduction factor of the bare frame and open ground story RC-infilled frame with lintel beam is less than the recommended value of the BIS (Bureau 
of Indian Standards) code, and the R-factor for the full RC-infilled frame with lintel beam satisfied the BIS code value. As highlighted by several studies together with ours, the $R$ factor is very sensitive to material strength and geometrical and structural configuration of the structure so it is difficult to predict the precise $\mathrm{R}$ value for the respective structures. The practicing engineers should calculate the $\mathrm{R}$ value for every structure instead of using the codal provision because if the $\mathrm{R}$ factor is underestimated/overestimated, ultimately it will significantly have impact on the design base shear of the structure as well as the cost of the structure. Presently, the BIS (Bureau of Indian Standards) code neglects the factors, namely irregularity, incorporation of infill, and lintel beam for the $\mathrm{R}$ factor of a structure.

In the current design procedure, engineers should strictly follow the earthquake resistant design and ductile detailing for improvement of the performance of the structure. They should also try to adopt the energy dissipation devices like damper, semi-interlocked bricks infill, shape memory alloy material, lintel beam, etc. for the achievement of the performance of the structure. The strong column-weak beam concept should be adopted while designing any structure. Structural member size should be maximum in such a way that reinforcement should not bend at the beam-column joint to avoid the congestion of reinforcement.

The damage patterns of various analysis schemes highlight that the full RC-SIM infilled frame displays better seismic performance when compared to the full RC-URM infilled frame due to the presence of semi-interlocked brick units in the frame structure.

Author Contributions: Conceptualization, M.R.S., D.-P.N.K. and S.M.; methodology, M.R.S., D.P.N.K. and S.M.; software, M.R.S.; validation, M.R.S., D.-P.N.K., S.M. and D.G.; formal analysis, M.R.S and D.-P.N.K.; investigation, M.R.S., D.-P.N.K. and S.M.; resources, D.-P.N.K., D.G. and S.M.; data curation, M.R.S. and D.-P.N.K.; writing—original draft preparation, M.R.S. and D.-P.N.K.; writingreview and editing, D.-P.N.K., S.M., P.R.M. and D.G.; visualization, M.R.S. and D.-P.N.K.; supervision, D.-P.N.K. and S.M. All authors have read and agreed to the published version of the manuscript.

Funding: This research received no external funding.

Institutional Review Board Statement: Not applicable.

Informed Consent Statement: Not applicable.

Data Availability Statement: Data is contained within the article.

Conflicts of Interest: The authors declare no conflict of interest.

\section{References}

1. Gautam, D.; Rodrigues, H.; Bhetwal, K.K.; Neupane, P.; Sanada, Y. Common structural and construction deficiencies of Nepalese buildings. Innov. Infrastruct. Solut. 2016, 1, 1-18. [CrossRef]

2. Gautam, D.; Chaulagain, H. Structural performance and associated lessons to be learned from world earthquakes in Nepal after 25 April 2015 (MW 7.8) Gorkha earthquake. Eng. Fail. Anal. 2016, 68, 222-243. [CrossRef]

3. Wang, Z.; Totoev, Y.; Page, A.; Sher, W.; Lin, K. Numerical simulation of earthquake response of multi-storey steel frame with SIM infill panels. In Proceedings of the 2015 World Congress on Advances in Structural Engineering and Mechanics (ASEM15), Incheon, Korea, 25-29 August 2015; pp. 1-20. Available online: http:/ /www.i-asem.org/publication_conf/asem15/6.ICEAS15/ 3f/F2G.4.ES359_1894F1.pdf (accessed on 10 October 2020).

4. Wang, Z.; Totoev, Y.; Lin, K. Non-linear static analysis of multi-storey steel frame with semi-interlocking masonry infill panels. In Brick and Block Masonry: Trends, Innovations and Challenges, Proceedings of the 16th International Brick and Block Masonry Conference (IBMAC 2016), Padova, Italy, 26-30 June 2016; CRC Press, Taylor and Francis Group: London, UK, 2016; pp. 1375-1382. [CrossRef]

5. Alguhane, T.M.; Khalil, A.H.; Fayed, M.N.; Ismail, A.M. Seismic assessment of old existing RC buildings with masonry infill in madinah as per ASCE. Int. J. Comput. Syst. Eng. 2015, 9, 52-63. [CrossRef]

6. Shendkar, M.; Pradeep Kumar, R. Response reduction factor of RC framed structures with semi-interlocked masonry and unreinforced masonry infill. Indian Concr. Inst. J. 2018, January-March, 24-28.

7. Chaulagain, H.; Rodrigues, H.; Spacone, E.; Guragain, R.; Mallik, R.; Varum, H. Response reduction factor of irregular RC buildings in Kathmandu valley. Earthq. Eng. Eng. Vib. 2014, 13, 455-470. [CrossRef]

8. Maheri, M.R.; Akbari, R. Seismic behaviour factor, R, for steel X-braced and knee-braced RC buildings. Eng. Struct. 2003, 25, 1505-1513. [CrossRef] 
9. Goud, S.S.; Pradeep Kumar, R. Rationalizing response reduction factor R for better performance of reinforced concrete framed buildings. In Proceedings of the National Conference on Recent Research Advances in Civil Engineering (RRACE-2014), Tamilnadu, India, 7-8 November 2014; pp. 1-6.

10. Smyrou, E.; Blandon, C.; Antoniou, S.; Pinho, R.; Crisafulli, F. Implementation and verification of a masonry panel model for nonlinear dynamic analysis of in-filled RC frames. Bull. Earthq. Eng. 2011, 9, 1519-1534. [CrossRef]

11. Miranda, E.; Bertero, V. Evaluation of strength reduction factors for earthquake-resistant design. Earthq. Spectra 1994, 10, 357-379. [CrossRef]

12. Elnashai, A.S.; Mwafy, A.M. Overstrength and force reduction factors of multistorey reinforced-concrete buildings. Struct. Des. Tall Build. 2002, 11, 329-351. [CrossRef]

13. Motiani, R.; Kunal, J.R.; Gahrana, S.; Nambiar, A.; Desai, M. Evaluation of response reduction factor by pushover analysis. Int. J. Struct. Eng. 2018, 9, 116-129. [CrossRef]

14. Nishanth, M.; Visuvasam, J.; Simon, J.; Packiaraj, J.S. Assessment of seismic response reduction factor for moment-resisting RC frames. IOP Conf. Ser. Mater. Sci. Eng. 2017, 263, 032034. [CrossRef]

15. Zahid, M.; Robert, D.; Shahrin, F. An evaluation of overstrength factor of seismic designed low rise RC buildings. Procedia Eng. 2013, 53, 48-51. [CrossRef]

16. Shendkar, M.; Mandal, S.; Pradeep Kumar, R.; Maiti, P.R. Response reduction factor of RC-infilled frames by using different methods. Indian Concr. Inst. J. 2020, April-June, 14-23.

17. Mandal, S.; Shendkar, M.R. Evaluation of response reduction factor of RC-infilled frames. In Proceedings of the 17th World Conference on Earthquake Engineering (17WCEE), Sendai, Japan, 13-18 September 2020; pp. 1-12.

18. Shendkar, M.R.; Mandal, S.; Pradeep Kumar, R. Effect of lintel beam on response reduction factor of RC-infilled frames. Curr. Sci. 2020, 118, 1077-1086. [CrossRef]

19. Grubišić, M.; Ivošević, J.; Grubišić, A. Reliability analysis of reinforced concrete frame by finite element method with implicit limit state functions. Buildings 2019, 9, 119. [CrossRef]

20. Rezaei Rad, A.; Banazadeh, M. Probabilistic risk-based performance evaluation of seismically base-isolated steel structures subjected to far-field earthquakes. Buildings 2018, 8, 128. [CrossRef]

21. Kalkan, E.; Kunnath, S.K. Adaptive modal combination procedure for nonlinear static analysis of building structures. J. Struct. Eng. ASCE 2006, 132, 1721-1731. [CrossRef]

22. Gupta, B.; Kunnath, S.K. Adaptive spectra-based pushover procedure for seismic evaluation of structures. Earthq. Spectra 2000, 16, 367-391. [CrossRef]

23. Antoniou, S.; Pinho, R. Advantages and limitations of adaptive and nonadaptive force-based pushover procedures. J. Earthq. Eng. 2004, 8, 497-522. [CrossRef]

24. Pacific Earthquake Engineering Research Center (PEER). PEER Strong Ground Motion Databases, Pacific Earthquake Engineering Research Center, University of California, Berkeley, CA, USA. 2020. Available online: https://peer.berkeley.edu/peer-strongground-motion-databases (accessed on 10 October 2020).

25. Chaulagain, H.C. Assessment of Response Reduction Factor of RC Buildings in Kathmandu Valley Using Nonlinear Pushover Analysis. MEng Thesis, Purbanchal University, Biratnagar, Nepal, 2010.

26. ATC-19:1995. Structural Response Modification Factors; ATC-19 Report; Applied Technology Council (ATC): Redwood City, CA, USA, 1995.

27. Park, R. Ductility evaluation from laboratory and analytical testing. In Proceedings of the 9th World Conference on Earthquake Engineering, Tokyo, Japan, 2-9 August 1988; Volume 8, pp. 605-616.

28. Newmark, N.M.; Hall, W.J. Earthquake Spectra and Design; Earthquake Engineering Research Institute: Berkeley, CA, USA, 1982.

29. IS 1893:2016. Criteria for Earthquake Resistant Design of Structures-Part. 1 General Provisions and Buildings; 6th Revision; Bureau of Indian Standards: New Delhi, India, 2016.

30. SeismoStruct-A Computer Program for Static and Dynamic Nonlinear Analysis of Framed Structures; Seismosoft Ltd.: Pavia, Italy, 2020. Available online: https:/ / seismosoft.com/ (accessed on 10 October 2020).

31. Smith, B.S. Behavior of square infilled frames. J. Struct. Div. (ASCE) 1966, 92, 381-403.

32. Mander, J.B.; Priestley, M.J.; Park, R. Theoretical stress-strain model for confined concrete. J. Struct. Eng. (ASCE) 1988, 114, 1804-1826. [CrossRef]

33. Mander, J.B.; Priestley, M.J.N.; Park, R. Observed stress-strain behavior of confined concrete. J. Struct. Eng. (ASCE) 1988, 114, 1827-1849. [CrossRef]

34. Yassin, M.H.M. Nonlinear Analysis of Prestressed Concrete Structures under Monotonic and Cyclic Loads. Ph.D. Thesis, University of California, Berkeley, CA, USA, 1994.

35. Menegotto, M.; Pinto, P.E. Method of analysis for cyclically loaded R.C. plane frames including changes in geometry and nonelastic behavior of elements under combined normal force and bending. In Proceedings of the ISBE Symposium on the Resistance and Ultimate Deformability of Structures Acted on by Well Defined Repeated Loads, Zurich, Switzerland, 2-5 September 1973; International Association for Bridge and Structural Engineering (IABSE): Lisbon, Portugal; pp. 15-22.

36. Crisafulli, F.J. Seismic Behavior of Reinforced Concrete Structures with Masonry Infills. Ph.D. Thesis, University of Canterbury, Christchurch, New Zealand, 1997. [CrossRef] 
37. Shendkar, M.; Pradeep Kumar, R. Influence of opening in infill on R factor of RC infilled frame structures. Indian Concr. Inst. J. 2018, October-December, 1-6.

38. IS-13920:2016. Ductile Design and Detailing of Reinforced Concrete Structures Subjected to Seismic Force; Bureau of Indian Standards: New Delhi, India, 2016. 